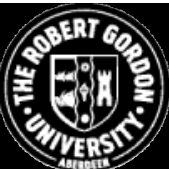

\title{
OpenAI R@RGU
}

\section{The Open Access I nstitutional Repository at The Robert Gordon University}

\author{
http://openair.rgu.ac.uk
}

This is an author produced version of a paper published in

New Technology-Based Firms in the New Millenium (ISBN

9780080554488)

This version may not include final proof corrections and does not include published layout or pagination.

\section{Citation Details}

Citation for the version of the work held in 'OpenAIR@RGU':

CHOREV, S. and ANDERSON, A. R., 2008. Experts' views on success factors for high tech start ups - lessons from Israel. Available from OpenAIR@RGU. [online]. Available from: http:/ / openair.rgu.ac.uk

\section{Citation for the publisher's version:}

CHOREV, S. and ANDERSON, A. R., 2008. Experts' views on success factors for high tech start ups - lessons from Israel. In: A. GROEN, R. OAKEY, P. VAN DER SIJDE and G. COOK, eds. New technology-based firms in the new millenium. Emerald. pp. 237-

\section{Copyright}

Items in 'OpenAIR@RGU', The Robert Gordon University Open Access Institutional Repository, are protected by copyright and intellectual property law. If you believe that any material held in 'OpenAIR@RGU' infringes copyright, please contact openair-help@rgu.ac.uk with details. The item will be removed from the repository while the claim is investigated. 
Experts' Views on Success factors for High Tech Start Ups - Lessons from Israel

Schaul Chorev and Alistair R Anderson

Charles P Skene Centre for Entrepreneurship

Robert Gordon University

Garthdee Road

Aberdeen AB 107QE

s.chorev@rgu.ac.uk

\section{Introduction}

Beyond the widely acknowledged importance of new business, the role of young exporting high-tech business in Israel and many other small economies is seen as vital for economic growth. Israel is small and geographically isolated from the main markets, suffers from security difficulties, but fosters a culture which promotes knowledge rich new technologies. Thus, new ventures with leading edge technologies and prospects of high growth and profitability offer a means to achieve the national goal of economical independence. Internationally however, the high-technology sector has recently suffered badly from the bursting of the dot.com bubble and the crash of the Nasdaq.

Prior to the collapse, the remarkable enthusiasm for new high-technology ventures led to quite unrealistic expectations about the profitability and sustainability of many of these new companies. A characteristic of companies formed during the overheated period was the elevation of ideas over substance and in particular, the lack of a sound business practices. Nonetheless, the potential value of these high-technology companies is recognized and there is some evidence of their gradual re-emergence under difficult circumstances. To aid the sustainability of this re-emergence, this study addresses the issue of viable business models that could enhance the prospects of success. Such a model of best practices, if properly grounded in the experiences of both successful and unsuccessful entrepreneurs, may provide a template to guide the formation and operation of new and growing high-tech companies. The contribution of this paper is twofold, first to collate the experiences of practitioners and secondly, to synthesise these into a model that identifies factors critical for success, and factors that are important, but not deemed essential and the roles they play in shaping success. 
Thus the study captures the implicit knowledge embedded in the experiences of entrepreneurs and others who are, or have been, engaged in the realities of high-tech venture creation. It categorises and synthesises this material and by analysis, establishes a practical model specifying the factors and their criteria seen to be critical for improving the success of high-technology new ventures. We developed a multi stage study, consisting of multiple interviews of key players to develop a model, which was then tested and refined in a pilot and a final survey. The nature of this study thus provides empirical evidence regarding the factors deemed necessary for successful high-tech venturing in Israel. The paper begins by considering the role of high-tech ventures for economic growth generally and in Israel in particular. We then explain our methodology that builds upon the existing literature. Key factors and their roles are identified. From this, we present our initial findings as a tentative model which we operationalised in our pilot study. Our revised questionnaire was completed by some 80 experts and finally refined in a Delphi review. From these data we arrive at our final model.

\section{Defining high-tech}

Although defining high-technology industries has been the subject of debate, (Oakey, Rothwell and Cooper, 1988) a broad definition of a high-tech business is one whose business activities are heavily dependent upon innovation in science and technology (Medcof, 1999). The characteristics of high-tech include; heavier investment in R\&D activities than the national average; employing a higher percentage of engineers and scientists among their staff; offer innovative and technologically advanced products; dynamic in nature and have short product development cycles (Oakey et al., 1988; Reeble, 1990, Covin and Slevin, 1991).

\section{High-tech in the Israeli context}

A number of authors have commented on the recent dramatic changes in the Israeli economy, (Dvir and Tishler, 1999; Lerner and Avrahami, 1999; Azulay, Lerner and Tishler, 2000; Israeli Ministry of Finance-International Division, 2003; Israeli Ministry of Finance - Economic and Research Department, 2003). The main changes in Israel can be summarized as:

- The market has opened up to foreign competition and investments;

- Absorbance of a considerable educated wave of immigration;

- Increase in government and private support in know-how infrastructure; 
- Shrinkage of the defense industry;

- Education levels have continued to improve;

- Changing lifestyle now attracts many youngsters into computer science, electronics and IT fields.

High-tech is the major driver of the Israeli economy, emphasized by a growth rate that is the highest of all Israeli industrial sectors. During the first half of 2000, the high-tech growth rate was $12 \%$, while the conventional industry growth rate was only $2 \%$. Hightech contributes $75 \%$ of the growth in Israeli GNP and 36\% of GNP (ICBS, 2001). At $3.5 \%$, Israel has the greatest $\mathrm{R} \& \mathrm{D}$ expenditure in the world as a percentage of GDP (Traston et al., 2002) and the highest number of start-ups in the world in relation to the population size.

A strong indicator of the substantial role of high-tech is the international comparison of venture capital investment. Figure 1 demonstrates that, internationally, Israel has the highest rate of $\mathrm{VC}$ investments, at $0.6 \%$ of GDP, in the high-tech sector. Remarkably, this is $50 \%$ higher than the US, three times higher than the UK and much greater than Germany or Japan.

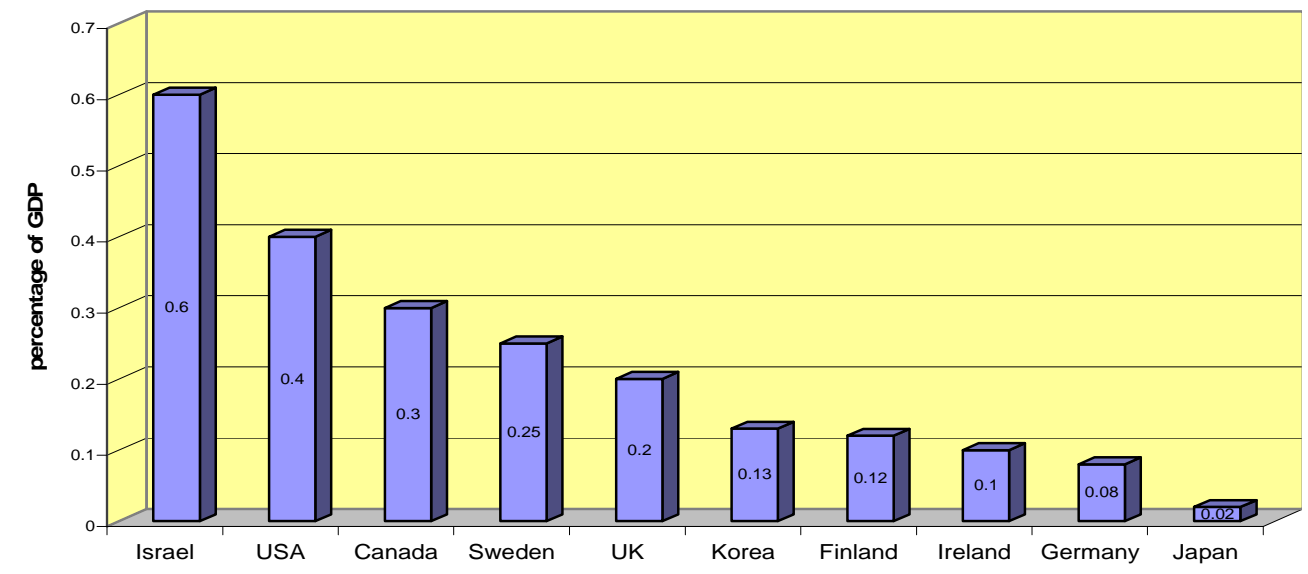

Source: Based on data from Israeli Export Institute

Figure 1: International Venture Capital Investment in high-tech as a percentage of GDP, 1999-2002

As an indicator of the volume of investment in high-tech, figure 2 indicates an apparent return of investor confidence. 


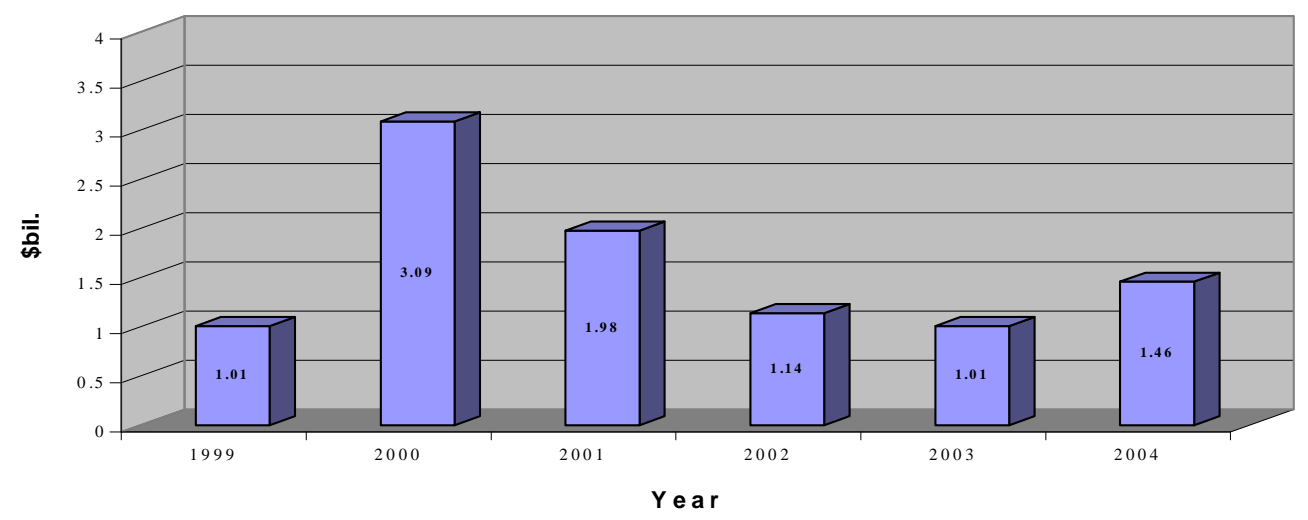

Figure 2: Capital raised by Israeli high-tech companies, 2000-2004

Source: Based on data from Israeli Venture Capital (IVC)

It is clear from the above that new high-tech firms play an important role in Israel. However, the nature of success, or even survival, is less obvious for these companies working at the leading edge of change. This is the issue addressed by this study. Based on the experience and tacit knowledge of high-tech venture leaders, what are the critical factors for success?

\section{Research methodology}

The study employed a multiple stage methodology described below.

\begin{tabular}{|c|c|c|}
\hline Step & Procedure & Outcome \\
\hline 1 & Literature Review & $\begin{array}{l}\text { Identify the main topics and parameters } \\
\text { influencing high-tech start-up success }\end{array}$ \\
\hline 2 & $\begin{array}{l}\text { Interviews \& informal } \\
\text { discussions }\end{array}$ & $\begin{array}{l}\text { Expand literature findings with additional issues } \\
\text { based on practical experience }\end{array}$ \\
\hline 3 & Initial Model & Construct a preliminary questionnaire \\
\hline 4 & Pilot Survey & Test Consistency and update the question \\
\hline 5 & Final Questionnaire & Analysis of the open and closed questions \\
\hline 6 & Final Model & $\begin{array}{l}\text { Research summary, conclusion and } \\
\text { recommendation }\end{array}$ \\
\hline 7 & Model validation & Endorsement of the model and its ranking \\
\hline
\end{tabular}

The first phase of the study was a literature review with the objective of building a list of the topics, and their main parameters, deemed as relevant for success of high-tech companies and high-tech start-ups; some are generic, whilst some are unique to Israel. After the literature review we employed an exploratory study. This exploration involved 14 in depth personal interviews with leading figures in the high-tech start-up 
community. The interviews were conducted with start-up managers who were involved in diverse fields of activity and at different life cycle stage, and with investors.

Thereafter the provisional model was operationalised into a survey instrument. We applied it as a preliminary questionnaire pilot survey in face to face interviews with expert respondents from twelve diverse start-ups. This pilot was intended to refine our instrument; overcome any lack of clarity and ambiguity; establish reliability and discover missing issues. The questionnaire was tested for consistency (Cronbach $\alpha$ ) and was modified in several steps to achieve the final questionnaire version.

The revised and final questionnaire included 42 questions and sub questions and consisted of the 15 model topics and with multiple item sets of questions for each dimension. We also included many open ended questions intended to tap into different types of responses to enquire about issues that could not be implemented in direct questions and to identify items that we had not anticipated. The final questionnaires were distributed through personal contacts and with the assistance of different organisations. The survey was completed by the CEOs or VPs of 70 high- technology start-up companies and by 10 Venture Capitalists or consultants. Israel as a small country, so we treated it as one cluster so that the sample population for the interviews and questionnaires was selected from all over the country.

The data were first analyzed qualitatively to investigate any unanticipated elements or patterns. This was followed by a statistical analysis of the findings, to establish a ranking of the topics and the major elements within each topic that were deemed critical and those seen as less important. From these data we developed a model. The final step was validation of the model by the Delphi method, where half of our respondents were asked to consider the model and rank it again. Using a panel of experts, the method proposes that the group will converge toward the "best" response through this consensus process (Linstone and Turoff, 1975). The midpoint of responses is statistically categorized by the median score. Our response rate for the final stage was $40 \%$, with a total of 16 verifying responses. 


\section{Factors Affecting high-tech start-up success}

In practice, most new ventures are better characterized by directed chaos than orderliness. However, to develop a conceptual viewpoint there is a need to establish a theoretical framework that articulates the formative dimensions of a new high-tech venture. Thus, the purpose of this section is to review the literature and to identify the conceptual categories considered important to new ventures. Cunningham (2000) asserts that more failures in high-tech can be attributed to business reasons than reasons associated with the technology. However, studies (Cooper, Gimeno-Gascon, and Woo, 1994; Dahlquist et al., 2000) suggest that there is no single dominant factor influencing the venture's destiny and that several dimensions shape the probability of success. Bell and McNamara (1991) describe the Bell Mason model (as shown below) that identifies four major fields and includes twelve distinctive dimensions (three in each field).

\begin{tabular}{|c|c|c|c|}
\hline Technology Product & Marketing/Sales & People & Finance/Control \\
\hline $\begin{array}{c}\text { Technology/Engineering } \\
\text { (R\&D) }\end{array}$ & Business Plan & CEO & Operations/Control \\
\hline Product & Marketing & Team & Finance-ability \\
\hline Manufacturing & Sales & $\begin{array}{c}\text { Board of } \\
\text { Directors }\end{array}$ & Cash \\
\hline
\end{tabular}

\section{The Bell Mason dimensions for start-up assessment}

Similarly, Macmillan et al. (1987) identify four dimensions; the entrepreneur, the product, markets and finance. Kakati (2003), critical of the poor predictive power of existing models, adds two additional elements - resource based capability and competitive strategy. Cooper et al. (1994) take a slightly different approach and specify four groups as predictors of new venture performance; general human capital, management know-how, industry-specific know-how and financial capital. Davidson and Klofsten (2003) describe a business platform of eight firm-level cornerstones; the business idea, the product, the market, the organization, core group expertise, core group drive/motivation, customer relations, and other relations. They explain that the cornerstones can be divided into the development process (idea, product, market, and organization), key persons (founder, CEO, board of directors - expertise and motivation) and the flow of external resources (customer and other firm relations). The process emphasis in Davidson and Klofsten's (2003) work, which was tested on young high-tech ventures, seems to capture the inter-dynamic nature of the new venture creation rather better than a static list of elements. In summary, the literature indicates 
six distinctive domains of new high-tech ventures; entrepreneurship, strategy, marketing, technology and products, management, finance and control. To this the impact of the external environment must be added.

\section{The role of factors in high-tech success}

The parameters described hereafter deal with the different domains influencing the success of high-tech start-ups, with a specific focus on the Israeli environment. We summarise the factors identified in a tentative theoretical model.

\section{Strategy}

The strategy goal is to achieve an advantage for the organisation through the configuration of resources within a demanding environment and is thus, (Johnson and Scholes, 2001) the long-term direction and scope of the organisation. Two schools advocate different start-up strategies to gain competitive advantage; the formal strategy led by frameworks such as Porter's (1980) 'Five Forces' model, analyzing the forces driving industry competition and the adaptive 'visionary' approach, proposed by Mintzberg (1994), whereby the organisation is run according to a mission, decisions are reached through learning and experience based on the intuition and creativity of key personnel.

One of management's most critical strategic choices is whether to compete broadly across many geographic segments or, alternately, to focus on a more limited set of geographic markets. Some researchers suggest a broad strategy for high growth markets and focused strategy whilst penetrating a mature market whilst others advocate focusing in the early stage of products. Several recent studies (Chandler and Hanks, 1994; Mahoney and Pandian, 1992) describe the importance of multiple strategies. Kakati (2003) argues that multiple strategies are the logical choice, provided the firm acquires multiple resources. However, since most small start-up ventures find it difficult to develop multiple resources to successfully implement broad strategies, the natural choice is to pursue a focus/customized strategy.

\section{Marketing}

Gardner et al. (2000) identify unique characteristics of the high-tech market environment; an earlier stage of the industry life cycle, greater degree of turbulence, higher product differentiation, higher market growth rate, shorter expected life cycle, a visible future for technology, easier entry into the market, more diverse suppliers and a 
higher level of consumer involvement in purchase decisions. These characteristics become especially relevant, given the small size of Israel's domestic market, firms typically need to penetrate foreign markets. Indeed, Frenkel et al. (1994), Steinberg (1999) and Goldman (2001) all emphasize access to overseas markets as essential for the survival of a start-up enterprise. Recent developments in the marketing literature provide an interesting insight into the entrepreneurial process. Market-driven capability, referred to as "market orientation" is defined as a systemic process of tracking trends and recognizing opportunities in the marketplace by utilizing intelligence generation and information dissemination activities (Day, 1999; Jaworski and Kohli, 1993; Slater and Narver, 1999). Cooper (1994) identifies strong market orientation - a market driven and customer focused New Product Process as a key success factor for new products. Market-oriented businesses usually seek to understand customers' expressed and latent needs and develop superior solutions to meet them (Kohli and Jaworski, 1990; Slater and Narver, 1995). Christensen and Bower (1996) claim that firms with a strong market orientation may however, over-emphasize current customer needs, possibly overlooking future products and growth opportunities; but other researchers, such as Slater and Narver (1998) disagree.

There is also disagreement amongst scholars about the importance of market attractiveness. Nesheim (1997) holds that the target market should be large and rapidly expanding, so the venture should consider market size, intensity of competition, revenue (and margins) potential over five years and potential customers. Mishra et al. (1996) find that markets growth and size are often most positively correlated with new product success. But conversely, Stuart and Abetti (1987) find a strong negative correlation between success in young technological companies and market attractiveness. Their study shows that companies entering smaller and slowly growing markets were doing better than those in the larger, faster growing markets. This may be due to a lower level of competitiveness and the avoidance of head-on competition with large and strong organisations. Nonetheless, there is broad agreement that expertise in marketing activity and marketing effectiveness of the new product diffusion are critical for the success of new products (Cooper and Kleinschmidt, 1990; Gardner et. al., 2000).

\section{Technology and product}

Great "devices" are invented in the laboratory, but great "products" are invented in the marketing department (Davidow, 1986). Cooper (1993) finds that the product must thus 
meet a market need. Cooper $(1979,1994)$ stresses the advantage of product uniqueness and superiority - products that are highly innovative and new to the market. Thus revolutionary breakthrough ideas are claimed to have a particular advantage; they are clearly differentiated and have high barriers for competitors. However, it is also harder to demonstrate market potential and to provide any evidence for sustainable profits (Christensen, 1997). Consequently the assessment of new "yet to be born" product market potential is difficult. Indeed, market research may indicate little interest (potential) at this stage. Nonetheless, Perlmuter (2003) argues that leaders and managers have to understand the markets and their limits and should channel their creativity to solutions that provide the customer with the complete product.

Development of new technology (Berry, 1996), or being first to market Cooper (1979), does not determine success. The issue of what the market wants and needs thus requires a combination of marketing and technical skills. Moreover, the importance of buyer/seller relationships, particularly in improving the new product development process, is a growing area of concern and study (Birou and Fawcett, 1994). Many researchers support the notion that there is a need for strong links between the R\&D department and other functional areas (Roberts, 1978, 1979; Wind, 1981, 1982; Goupta, Raj and Wilemon, 1986 and Von Hippel, 1978). Goupta and Wilemon (1990) describe the relationship between $R \& D$ and marketing as one aimed at successful product innovation. Young (1973) and Souder $(1977,1981)$ note that the failure to integrate R\&D and marketing at an early stage of the innovation process, is one of the biggest contributors to new product failure.

\section{Management}

High-tech is an evolutionary and fast moving environment and corporate survival depends upon successfully managing that evolution (Leonard-Barton, 1992). The pace of environmental change requires start-ups to be managed, not only by skilled managers, but also by a team capable of managing changing markets (Eisenhardt and Brown, 1998). Roure and Maidique (1986) demonstrate that founders of successful high-tech ventures tend to form larger, more complete teams. Thus a diversified management team, in which technological expertise coexists with business skills in other key areas such as marketing and finance, is recognised as a deciding factor for success in high-tech start-ups (Roberts, 1968, Cooper 1973). High-performance new firms are rarely started by individuals; $80 \%$ are established by teams (Reynolds, 1993). 
Moreover, Chandler and Hanks (1998) and Roure and Keely (1990) find team completeness and previous joint experience to be strongly associated with firm performance.

\section{Finance}

Most high-tech start-ups acquire seed funding then raise additional rounds of capital until exit or acquisition; most successful high-tech start-ups eventually become public or are procured by a larger company. Funding is thus the oxygen of start-ups. In Israel. Lerner and Avrahami (2002) note the ready availability of funds for new enterprise and that venture capital is a major source of funding. One recent difficulty commented upon was the reduction of government guarantees to new entrepreneurs. After the Nasdaq collapse in 2000 there was a substantial decrease in foreign investment in Israel, but by 2004 the uptrend returned to VC funds' inflow to the high-tech sector.

Several studies have reported important value added benefits provided by venture capitalists. These benefits include help in obtaining additional financing, improving investment decisions and providing non-financial assistance such as strategic planning and help in recruiting key executives (MacMillan et al., 1989; Gorman and Sahlman, 1989; Sapienza, 1992; Goupta and Sapienza, 1992; Sapienza et al., 1996; Hellman and Puri, 2001). But recent studies show that VCs are overconfident in their decision process and this negatively affects the accuracy of their decisions (Zacharakis and Shepherd, 2001). Moreover, Israeli VCs and their allies, the US investment bankers, claims Bainerman (2002), are solely concerned with quick exits and not with the once noble concept of building enterprises for the long-term and for the benefit of the entire country.

\section{External environment}

Specht (1993) classifies five main environmental factors affecting organisation formation;

social - impact of networks, cultural acceptance;

economy - capital availability, aggregate economic factors and unemployment;

political - support of public or semi public agencies; infrastructure development several aspects such as the education system, the nature of the local labor market, incubator organisations, information accessibility and availability of premises; 
market emergence - integrates concepts of niche emergence and technological innovation.

Perlmuter (2003) claims that the best solution for preserving high-tech competitiveness is a strong education system providing broad knowledge. In Israel, the Defense Forces (IDF) have special education programs such as Talpiot and Psagot, to provide selected highly talented youngsters with a high level technological education. Many high-tech start-ups include graduates of these programs and graduates of the IDF's special technology units. Moreover, some of the most successful high-tech start-ups stemmed from entrepreneurs formerly employed by the defense industry utilizing knowledge acquired in those organisations.

\section{The Theoretical Model}

The model in figure 3 dubbed "the theoretical model" is based on the findings of the literature review. This model is later reshaped into the final research model after including the data collected from the in depth interviews' during the primary research. The major parameters of each topic were included in the research questionnaire and analyzed in the findings of the empirical research.

The literature review established that some areas as potentially having high importance. The Product and the Complete Solution emerged as separate issues closely related to Marketing and R\&D. Other topics that have been emerged are the Networking and the importance of the Core Team, including the entrepreneurs/founders and the CEO which is often one of the founders. The Core Team seems to have a crucial importance and hence is divided into two separate areas: Core Team Expertise and Core Team Commitment. The way of Organization is a managerial issue which can have an effect on the company culture and hence the attitudes and motivation of the employees. It has therefore been separated from other general managerial issues. 


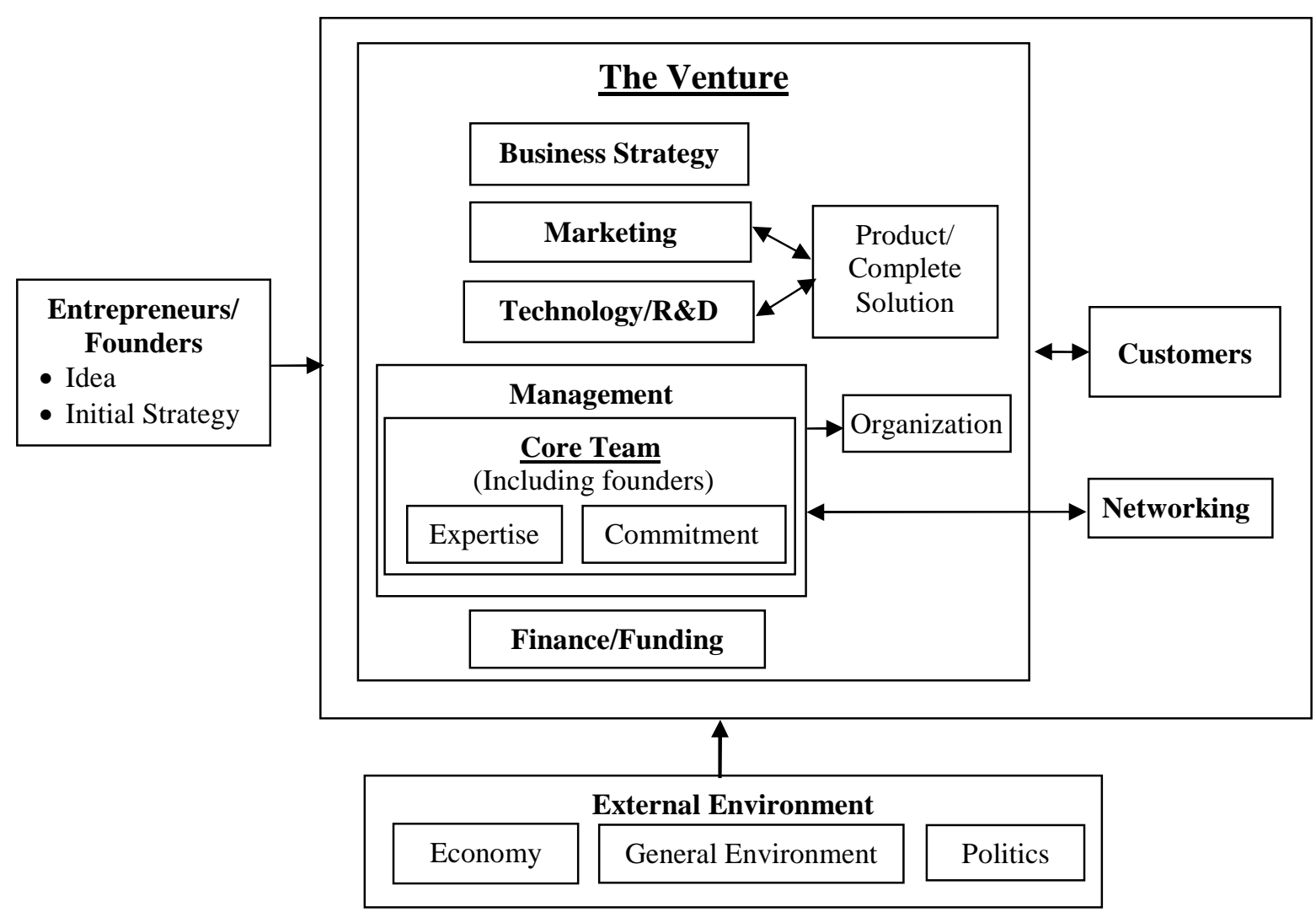

Figure 3: The expanded theoretical model

\section{The Empirical Research}

The empirical study started with interviews of 14 recognised leaders of the high-tech community. The respondents made a number of observations that we captured to supplement the main issues revealed during the literature review and include in the final survey instrument. These are paraphrased below:

1. Strategy was emphasized as navigating the organisation. The business plan has to be clear and based on realistic market needs. A major fault in many start-ups is a focus on technology.

2. Core Team expertise, diversified knowledge and harmony are essential for success. Very often start-ups are founded by young people who themselves lack management skills and experience but hesitate to hire suitable managers. At certain stages, where the start-up encounters gaps or lacks expertise, consultants can be useful.

3. Personnel should be selected very carefully. Almost every employee has a major effect on the accomplishments of the start-up.

4. The "bubble" period created "hot" funds that had to be invested urgently. Investors who were directors often lacked the competence to assist the start-up. 
5. Most start-ups stem from engineers and scientists who often believe, erroneously, that a good product will sell. Marketing is not always seen as a profession and marketing departments are established very late (often too late). The "professionals" should know the market; select the correct market niche, and continuously update the marketing strategy. Products that require market education should be avoided because of the lengthy and resource demanding process. Customer's needs should be well understood and their feedback implemented.

6. The product should provide a complete solution (if not sold to OEM) and has to meet real needs and provide good quality. Easy adaptation to different needs (markets and applications) is a big advantage.

7. $R \& D$ should take advantage of the unique technologies existing in Israel and the skilled workforce available in the market.

8. Strategic alliances with key customers, other companies or marketing organisations are often the key to success.

9. Funding has to be timed correctly, because of fluctuations in the economy.

10. Investors do not always add value, sometimes they become an obstacle.

\section{Ranking of topics importance}

In the questionnaire respondents were first asked (in part 1) to rank each of the 15 topics and its associated parameters on a Likert scale of 1-7, where 7 implies "most important". Respondents were also asked questions about details of the topics to identify any additional issues. Table 1 presents the findings of the ranking.

The data confirms that the list of "important" topics was correct; no topic or parameter was ranked lower than 4.2. Perhaps the most revealing aspect of the data in this part was the high ranking placed on the team. Team commitment was ranked highest at 6.47 and team expertise was ranked 4th at 6.13. Other topics identified as highly important were marketing 6.17; customer relationships 6.15; core team expertise 6.13 and management, 6.05. strategy 6.0, R\&D 5.95 and idea 5.89 complete the list of the top eight topics which formed the group of high effect factors on start-ups success. The following seven topics, starting with networking at 5.46, were ranked much lower and are perceived to belong to the second group, deemed to have a relatively lower impact. 
Table 1: Ranking of the importance of the topics

\begin{tabular}{|c|c|c|c|c|c|}
\hline & Mean & SD & & Mean & SD \\
\hline Idea & 5.89 & 1.240 & Strategy & 6.00 & 1.140 \\
\hline Idea formulation & 5.87 & 1.390 & Mission statement & 5.30 & 1.555 \\
\hline Idea meets customer needs & 6.27 & 1.136 & Industry analysis & 5.99 & 1.138 \\
\hline Core team expertise & 6.13 & 1.018 & Strategy clarity & 5.09 & 1.487 \\
\hline Team diversified experience & 5.95 & 1.142 & Strategy update & 5.82 & 1.295 \\
\hline Team former experience & 5.04 & 1.490 & Core team commitment & 6.47 & .936 \\
\hline Team leadership capacity & 6.32 & 1.183 & $\begin{array}{l}\text { Core team association with } \\
\text { goals }\end{array}$ & 6.46 & .921 \\
\hline Consultants & 5.24 & 1.478 & Core team motivation & 6.58 & .919 \\
\hline Investors' contribution & 4.64 & 1.450 & Marketing strategy & 6.17 & 1.088 \\
\hline Organization & 4.95 & 1.327 & Market expertise & 6.03 & 1.240 \\
\hline $\begin{array}{l}\text { Employee definition of } \\
\text { responsibility domains }\end{array}$ & 5.08 & 1.238 & Marketing plan & 6.01 & 1.051 \\
\hline Few organizational levels & 5.19 & 1.368 & Marketing research & 5.08 & 1.457 \\
\hline Customer Relationship & 6.15 & 1.110 & Market growth & 5.22 & 1.324 \\
\hline Customer needs & 6.15 & 1.167 & New market standards & 4.78 & 1.533 \\
\hline Customer buying behavior & 6.16 & 1.126 & \begin{tabular}{|l|} 
International market \\
penetration
\end{tabular} & 5.69 & 1.252 \\
\hline Feedback implementing & 6.15 & 1.167 & Market dynamics & 5.75 & 1.286 \\
\hline Market receptivity & 6.11 & 1.173 & Patents registration & 5.36 & 1.751 \\
\hline Continual sales & 5.53 & 1.588 & Perceived utility & 6.34 & 1.120 \\
\hline Management in general & 6.05 & 1.250 & Distribution channels & 4.63 & 1.538 \\
\hline Management style & 5.27 & 1.588 & Product positioning & 5.56 & 1.383 \\
\hline Team solidarity & 5.99 & 1.204 & Marketing R\&D relationship & 5.96 & 1.265 \\
\hline Employee development & 5.63 & 1.300 & Main market penetration & 5.92 & 1.285 \\
\hline Networking in general & 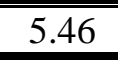 & 1.241 & R\&D capability & 5.95 & 1.038 \\
\hline Complete solution & 5.36 & 1.485 & \begin{tabular}{|l} 
Technological manpower \\
availability
\end{tabular} & 5.78 & 1.141 \\
\hline A gadget & 4.64 & 1.455 & \begin{tabular}{|l|}
$\begin{array}{l}\text { Defense technology and } \\
\text { infrastructure }\end{array}$ \\
\end{tabular} & 4.23 & 1.806 \\
\hline Complete product & 5.39 & 1.561 & Development team & 5.95 & 1.161 \\
\hline Cooperation in $\mathrm{R} \& \mathrm{D}$ & 5.31 & 1.528 & Innovation level & 5.70 & 1.358 \\
\hline Cooperation in marketing & 5.71 & 1.426 & Technological breakthrough & 5.34 & 1.353 \\
\hline Funding Type & $\begin{array}{l}5.31 \\
\end{array}$ & 1.303 & Easiness of adaptation & 5.55 & 1.341 \\
\hline Political situation & $\begin{array}{c}4.34 \\
\end{array}$ & 1.553 & Product quality and durability & 6.12 & 1.256 \\
\hline Political environment & 4.39 & 1.658 & \begin{tabular}{|l|} 
Product price \\
\end{tabular} & 5.71 & 1.346 \\
\hline Security situation & 4.26 & 1.708 & Time to market & 5.41 & 1.480 \\
\hline General Environment & 4.96 & 1.219 & Economic Situation & 5.43 & 1.271 \\
\hline Military service & 4.45 & 1.730 & Global economy & 5.63 & 1.340 \\
\hline Entrepreneurship education & 4.85 & 1.387 & Domestic economy & 4.79 & 1.586 \\
\hline $\begin{array}{l}\text { Availability of skilled } \\
\text { workforce }\end{array}$ & 5.64 & 1.259 & $\begin{array}{l}\text { Availability of financial } \\
\text { resources }\end{array}$ & 5.82 & 1.246 \\
\hline Government support & 4.89 & 1.420 & & & \\
\hline Cultural and social norms & 5.18 & 1.325 & & & \\
\hline
\end{tabular}


We were interested to note that the complete solution was ranked as considerably less important than the human elements. Also funding type was not seen as critical. This may reflect the unique Israeli position in which the high involvement of VCs in hightech start-ups generated disappointment because of the poor added value of the VCs. Both the general environment and the political situation were not highly rated, but the economic situation was seen to have some importance. Thus, in many ways we see confirmation of the literature: a good team will be successful and that the actual product is less critical. Moreover, the data suggests that a good team will succeed, even in poor economic, environmental and political circumstances.

To obtain better discrimination between topics then (in part 2 of the survey) the respondents were asked to focus on the topics ranking. They were asked to classify the topics into one of three groups, very important, important and less important and afterwards to rank the topics within each group. We could thus establish an overall rating of 1 (the most important topic) to 15 (lowest importance) for each of the topics. The final part of the study involved asking half of the respondents to comment on the results of the general survey (Delphi method).

Figure 4 is a summary of the rankings and compares the overall ranking in part 2 with the outcome of the Delphi ranking. It demonstrates a broad trend towards agreement over the relative importance of the different topics although some minor disagreements over the relative ranking of the critical components are observed. The primary group that contains 8 topics deemed of highest importance and the 7 topics of the secondary group with a lower impact are clearly delineated. Both groups consist of the same topics identified in part 1 of the questionnaire. There are five topics that are ranked at the top. This implies that all features associated with the core team (commitment and expertise), the idea, strategy and marketing are considered critical for the new high-tech venture. Customer relationship, management and $R \& D$ also belong to the high impact. Less important topics are networking, funding type, the economy, the complete product and the organization while the external factors of general environment and political situation are ranked at the bottom (as in part 1) and apparently have the lowest influence on the fate of the start-up. 
Figure 4: The respondents ranking of the topics

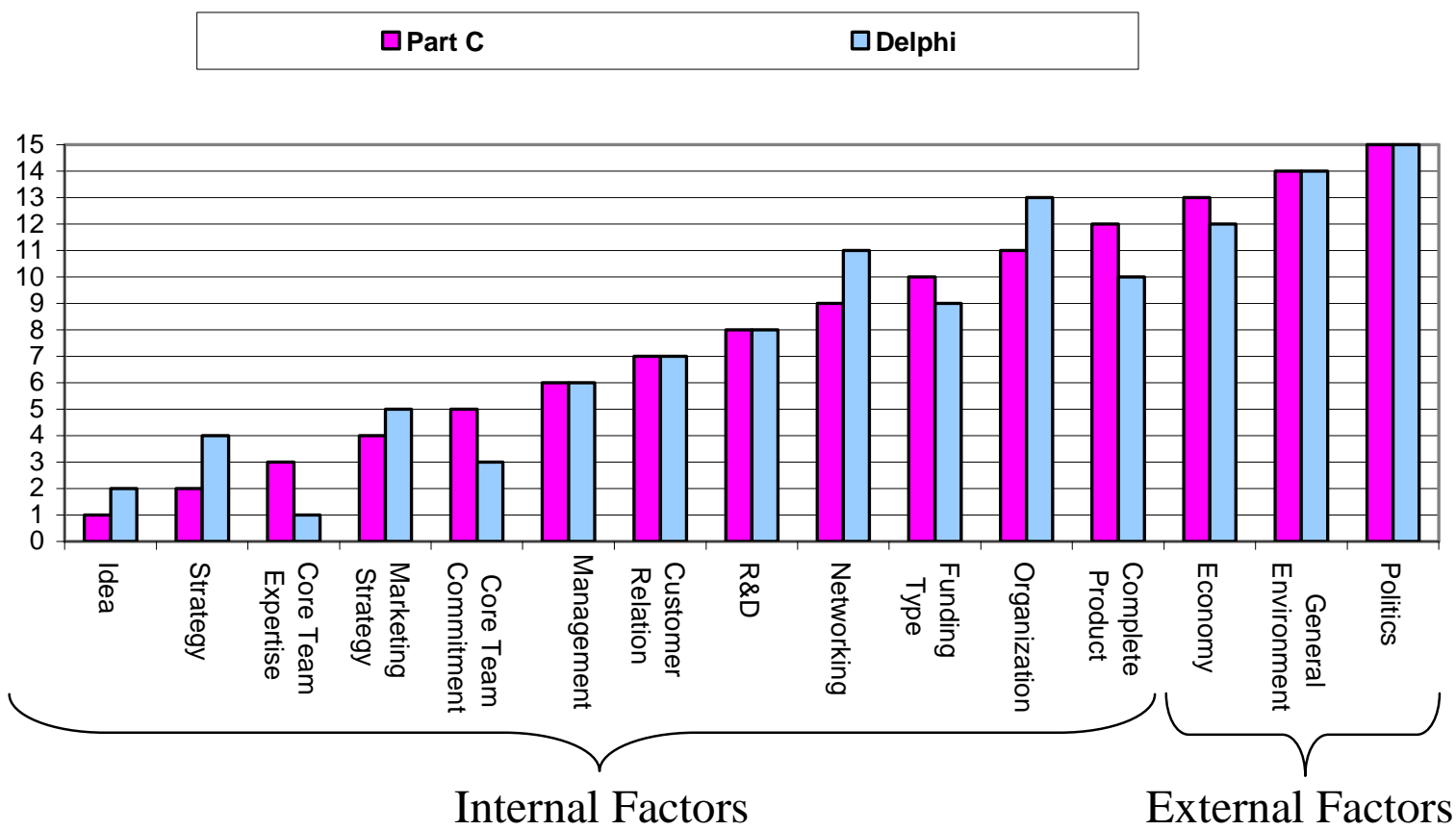

In the ranking of part 2 and in the Delphi method, the idea and strategy were ranked much higher than in part 1 . It seems possible that when forced to consider the relative importance of each topic, the respondents, recognized that without a good idea and a decent strategy to make it work, the other elements became secondary. In the first section, where respondents rated each topic individually, the importance of the team may have been prioritized on some sort of tacit assumption that the idea had been reasonable to begin with.

Although there were some differences in the scores attached to the ranking of the topics between companies defined as successful and those defined as unsuccessful or between the ranking of experts and the start-up community the overall positions in the rankings are very similar. The same conclusion was attained when the represented companies were divided into two groups, hardware companies (such as communication and electronic systems) and science and IT companies (Internet, software, life science, biotechnology). It manifests that most people involved in start-up activities have similar opinions about the level of importance of the different issues, some of it gained probably by similar real life experience.

\section{The Final model utilizing the research results}

The survey and Delphi results provide some confidence that the list of factors identified from the literature represent the factors deemed important by experienced practitioners. 
Moreover, the general agreement about the critical factors demonstrates their significance. This section elaborates on these findings by incorporating the responses to the open-ended questions.

The core team was identified as vital for success, thus both of the topics representing the core team - core team commitment and core team expertise - were placed at the top of the list. The two major factors relating to commitment - team motivation and association with the start-up goals - were emphasized. High importance was assigned to leadership capability and the diversity of team experience. This suggests that the core team is possibly more important than any other topic. Many respondents claimed that with a strong and committed team the start-up will succeed. The market may shift, the strategy could change, but ultimately people create success. Former experience was, surprisingly, ranked low. The investors' contribution was also evaluated as very low. This was probably an outcome of the general disappointment, commented upon in the interviews and open questions, about their investors' strategic or networking contribution.

The topic idea was also ranked very highly, as was the related subject, the necessity to meet customer needs, which appeared crucial to success in the market. Respondents commented that too many start-ups develop interesting products with innovative hightechnology but with no real market need. Sometimes a breakthrough technology may introduce a product too early for the market. Examples cited included many products launched in 2000 and 2001 intended for the third generation of cellular communications.

Strategy was considered important, with an emphasis on future trend analysis and continuous updating. However, clear strategy at the outset and clear mission statement are not viewed as important. This was explained by noting how the typical start-up dynamic situation requires great flexibility in strategy formulation and adaptation. This data identified marketing as vital. Respondents allocated high importance to product perceived utility, comprehensive knowledge of the market, reliable marketing plan and the marketing and R\&D relationship. Supporting distribution channels did not receive a high score nor was the idea of creating new markets with new standards. Respondents suggested that educating the market is too costly. 
Management capability and the team solidarity within the enterprise were observed as important, particularly with reference to "core team association with goals". Nonetheless, no priority was given to a specific management style and it was argued that management style should adapt to each individual venture.

The relationship with customers was cited as a key driver of sales. Almost all parameters related to this topic are considered to have high priority. Personal acquaintance with the targeted customers, understanding the customer's buying behavior, implementation of customers' feedback and market receptivity for the product were all noted. Only the parameter related to opportunities for continual sales was ranked with a somewhat lower importance. R\&D was considered important, particularly in linking with the market. The quality of the R\&D team and the product durability were seen as imperatives. Networking in marketing (to open doors into the target market niche) and finance (to assist future fund raising) are perceived as very valuable.

The issue of a complete product is somewhat complex and might have been misunderstood by some respondents. Although a complete solution was not ranked very highly, responses recognized that the market seeks a complete solution. A possible reason proposed was that many start-ups plan on selling directly to OEMs (Original Equipment Manufacturers), which market the complete product/solution and others plan marketing alliances as a solution to address market needs.

The economy is not seen as a main factor in success, but the availability of funds was seen as related to the global economical situation; funds should be raised when available and not when urgently needed. Most of the general environment parameters were ranked with low importance. However, many respondents noted that military service in Israel affects the capabilities of the young generation. Some of the skills gained during military service, such as improvisation skills were considered helpful in start-up regimes. Although the political situation and its parameters, the political environment and the security situation in Israel had amongst the lowest rankings, this may be a result of misconception. Some respondents noted that start-up leaders may lack awareness and understanding of the real world behavior, particularly when selling to large overseas organisation. 


\section{The final model}

Figure 5 depicts the final research model. The model highlights the topics (bold fonts within the figure) deemed to be critical for success (the group of topics with highest importance) and their key elements. As can be observed, the important topics namely, the idea; strategy; core team commitment; core team expertise; marketing; management; customer relations and $\mathrm{R} \& \mathrm{D}$ are relevant for start-ups in general. So although the data indicated that some factors were important in Israel these were not ranked very high. For example, team solidarity is perceived as very strong in Israel due to the influence of the military service and possibly provides a unique advantage to Israeli start-up ventures; Availability of skilled work force - again a possible advantage for Israeli start-ups due to the high level of technological education and the large influx of educated and skilled immigration from Russia during the 1990s. Penetration of the international market scored relatively high, but is true for any start-up that has a limited domestic market. The global economy has a general influence on the willingness to buy new products in general and from small and distant start-up in particular, but has also a strong influence on the availability of Venture Capital funds that play a major role in financing Israeli high-tech start-ups. 
Figure 5: The Final Model

- Product perceived utility

- Comprehensive acquaintance with the market

- Reliable marketing plan

- Marketing R\&D Interface

Motivation of the team

- Association with startup goals

- Personal acquaintance

- Understanding customer's buying behavior

- Implementation of feedback

- Market receptivity for the product

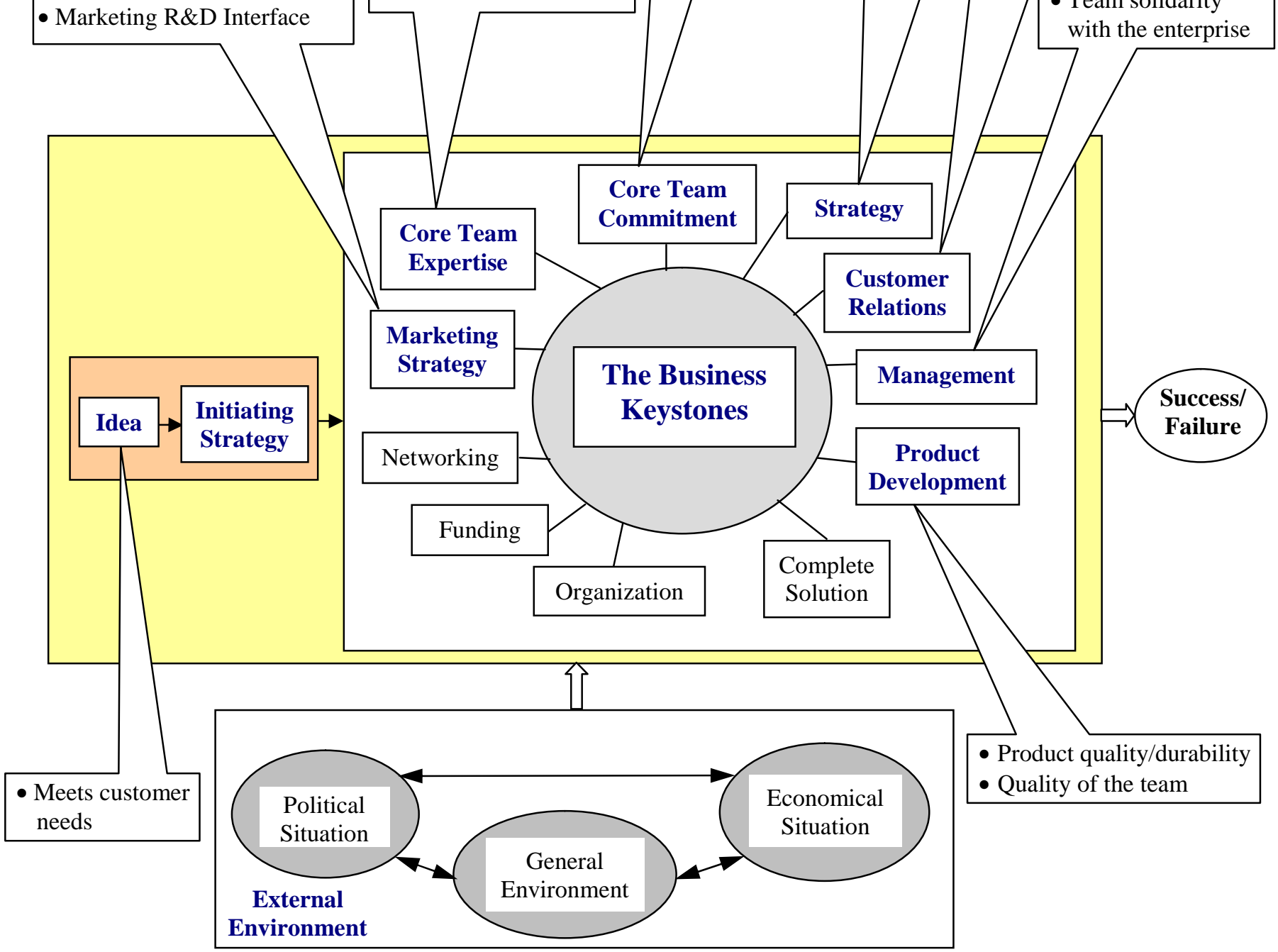




\section{Conclusions}

The attempt to establish a practical model of critical success factors for application by nascent, emergent and growing companies in the high-tech sector appears to have been successful. The data shows a high level of consistency and reliability and demonstrated two categories of topics; those of the highest importance and those ranked less critical. The first group included, the commitment of the core team, their expertise, the idea itself, strategy in general and marketing strategies; customer relationships, management and $R \& D$ capacity. Those less critical were seen as networking, type of funding, the economy, a complete product, organization, the general environment and politics.

The research results clearly manifest some valuable aspects which should be considered by the start-up leaders:

- The value of the people. In the business world involving high-tech, where creative thinking and comprehensive understanding of the volatile markets are vital for success, the most important asset seems to be an excellent and motivated staff.

- A start-up suffers from limited resources. The creative minds of the engineers and the new opportunities arising almost daily, are a dangerous combination. The ability to prioritize opportunities and to focus in terms of strategy, products and markets is crucial for success.

- Lack of resources often prevents developing a complete solution. In this case leveraging the strengths of others could be an optimal solution. Selling to OEMs which integrate the start-up product and/or using their networking in marketing and sales can be very beneficial. A strategy integrating partnership agreements can be very rewarding.

- The "rush for gold" period is over and investment returned to utilize economic logic. The start-up should raise money when possible and not wait until it is urgently needed.

- A start-up should strive to overcome local weaknesses. In Israel for example weaknesses were identified in management skills and international marketing.

- Don't be dogmatic, open eyes to new markets and opportunities. 
- The external environment has a relatively low effect on success and should not be a barrier from entrepreneurial high-tech start-up activity.

We do not propose that the study represents an entirely inclusive picture of new venture performance because there are always variables that may have been omitted. It is suggested that the research model contains a more comprehensive approach than previously considered. Although the model has reliability and validity, detailed enhancement could improve its practical utility. Further research on larger and broader samples in different environments, cultures and industries may yield a model with broader applicability. The final model envisioned should have a multi-dimensional matrix specifying the detailed description of the necessary elements in each topic and the desired level of achievement depending on variables such as the different stages of the company life cycle, industry, and geographic region.

Our model is derived from the extensive experience of many of leading Israeli experts. In consequence, it is soundly grounded in experience and knowledge and should have a very practical utility. The application of the model may enable new firms to identify and assess their capacities and thus to change, modify, amend or to acquire capacity to improve success rates. Whilst the model is based on the Israeli environment and experience, many other countries geographically distant from their main markets share many of these characteristics, so the model may have general utility. The model has still to be tested for causality, but could be adapted and expanded; hence it provides ample opportunities for future research. 


\section{References}

Azulay I., Lerner, M., Tishler A., 2000. Converting military technology through corporate entrepreneurship. The Israel Institute of Business Research.

Bainerman, J., 2002. Broken promises - the rise and fall of Israel's technology based industries. P.O.B. 387 Zichron Yaacov, Israel, 30900. (Unpublished).

Bell, G., McNamara, J., 1991. High-tech ventures - The guide for entrepreneurial success. Addison-Wesley, MA.

Berry, M.M.J., 1996. Technical entrepreneurship, strategic awareness and corporate transformation in small high-tech firms. Technovation 16 (9), 487-498.

Birou, L.M., Fawcett, S.E., 1994. Global supplier involvement in integrated product development: a comparison of U.S. and European practices. International Journal of Physical Distribution and Logistics Management 24 (5), 4-14.

Chandler, G.N., Hanks, S.H., 1994. Market attractiveness resource-based capabilities, venture strategies, and venture performance. Journal of Business Venturing 9 (4), 331-349.

Chandler, G.N., Hanks, S.H., 1998. An investigation of new venture teams in emerging businesses. Frontiers of entrepreneurship research. Wellesley, Babson College, MA.

Christensen, C.M., 1997. The innovator's dilemma: when technologies cause great firms to fail. Harvard Business School Press, Boston, MA.

Christensen, C.M., Bower, J.L., 1996. Customer power, strategic investment, and the failure of leading firms. Strategic Management Journal 17 (3), 197-218.

Cooper, R.G., 1973. Technical entrepreneurship: what do we know? R\&D Management $3(2), 59-64$.

Cooper, R.G., 1979. The dimension of industrial new product success and failure. Journal of Marketing 43 (3), 93-103.

Cooper, R.G., 1993. Winning at new products: accelerating the process from idea to launch. Addison-Wesley, Reading, MA.

Cooper, R.G., 1994. New products: the factors that drive success. International Marketing Review 11 (1), 60-76.

Cooper, A.C., Gimeno-Gascon, F .J., Woo, C.Y., 1994. Initial human and financial capital as predictors of new venture performance. Journal of Business Venturing 9 (5), $371-395$.

Cooper, R.G., Kleinschmidt, E.J., 1990. New product success factors: a comparison on "kills" versus successes and failures. R\&D Management 20 (1), 47-63. 
Covin, J.G., Slevin, D., 1991. A conceptual model of entrepreneurship as firm behavior. Entrepreneurship Theory and Practice 16 (1), 7-25.

Cunningham, C., 2000. Technology Diaspora: Israeli high-tech industry faces a modern day exodus. Red Herring, Special Report on Israel 82, 252-257.

Dahlquist, J., Davidson, P., Wilkund, J., 2000. Initial conditions as predictors of New Venture Performance: A replication and extension of the Cooper et al. study. Enterprise \& Innovation Management Studies 1 (1), 1-17.

Davidow, W., 1986. Marketing high-technology. The Free Press, New York, NY.

Davidson, P., Klofsten, M., 2003. The Business Platform: developing and instrument to gauge and to assist the development of young firms. Journal of Small Business Management 41 (1), 1-26.

Day, G.S., 1999. Creating a market-driven organization. Sloan Management Review 41 (1), 11-22.

Dvir, D., Tishler A., 1999. The changing role of the defense industry in technologicalindustrial development in Israel. The Israel Institute of Business Research, Tel Aviv. (In Hebrew).

Eisenhardt, K.M., Brown, S.L., 1998. Time pacing: competing in markets that won't stand still. Harvard Business Review 76 (2), 59-69.

Frenkel, A., Reiss, T., Maital, S., Koschatzky K., Grupp, H., 1994. Technometric evaluation and technology policy: the case of biodiagnostic kits. Research Policy 23 (3), 281-292.

Gardner, D.M., Johnson, F., Moonkyu, L., Wilkinson, I., 2000. A contingency approach to marketing high-technology products. European Journal of Marketing 34 (9/10), 1053-1077.

Goldman, N., 2001. Israeli marketing: A work in progress. Israeli High-Tech Investor February, 44-45.

Gorman, M., Sahlman, W.A., 1989. What do venture capitalists do? Journal of Business Venturing 4 (4), 231-248.

Goupta, A. K., Raj, S. P. and Wilemon, D., 1986. A model for studying R\&Dmarketing interface in the product innovation process. Journal of Marketing 50 (2), 7-17.

Goupta, A.K., Sapienza, H.J., 1992. Determinants of venture capital firms' preferences regarding the industry diversity and geographic scope of their investments. Journal of Business Venturing 7 (5), 347-362.

Goupta, A.K., Wilemon, D., 1990. Improving R\&D - Marketing relations. R\&D Management 20 (4), 277-289.

Hellman, T., Puri, M., 2001. Venture capital and the professionalization of start-up firms: empirical evidence. Journal of Finance 57 (1), 169-197. 
Israel Central Bureau of Statistics (ICBS)., 2001. Annual report. Government Publishing House, Jerusalem. (In Hebrew).

Israeli Ministry of finance - International Division., 2003. The Israeli economy at glance. http://www.mof.gov.il/beinle/ie/glance_eco2003.htm

Israeli Ministry of finance - Economic and Research Department., 2003. Economic outlook. http://www.mof.gov.il/research_e/eo03_03/mainpage.htm

IVC - Israel Venture Capital research center., 2004. Summary of Israeli high-tech company capital raising Q4 2004 and full year 2004. http://www.ivc-online.com

Jaworski, B. J., Kohli, A. K., 1993. Market orientation - antecedents and consequences. Journal of Marketing 57 (3), 53-70.

Johnson, G., Scholes, K., 2001. Exploring corporate strategy: text and cases, 6th ed. Prentice Hall, London.

Kakati, M., 2003. Success criteria in high-tech new ventures. Technovation 23 (5), 447457.

Kohli, A.K., Jaworski, B.J., 1990. Market orientation-the construct, research propositions, and managerial implications. Journal of Marketing 54 (2), 1-18.

Leonard-Barton, D., 1992. Core capabilities and core rigidness: A paradox in managing new product development. Strategic Management Journal, Summer Special Issue $13,111-125$.

Lerner, M. and Avrahami, Y., 1999. Global entrepreneurship monitor: Israel executive report. Tel Aviv University, Tel Aviv.

Lerner, M. and Avrahami, Y., 2002. Global entrepreneurship monitor: Israel executive report. Tel Aviv University, Tel Aviv.

Linstone, H., Turoff, M., 1975. The Delphi method. Addison-Wesley, Reading, MA.

MacMillan, I.C., Zemann, L., Subbanarasimha., 1987. Criteria distinguishing successful from unsuccessful ventures in the venture screening process. Journal of Business Venturing 2 (2), 123-137.

MacMillan I.C., Kulow, D.M., Khoylian, R., 1989. Venture capitalists' involvement in their investments: Extent and performance. Journal of Business Venturing 4 (1) $27-47$.

Mahoney, J.T., Pandian, J.R., 1992. The resource-based view within the conversation of strategic management. Strategic Management Journal 13, 363-380.

Medcof, J.W., 1999. Identifying 'Super-Technology' industries. Research Technology Management 42 (1), 31-36.

Mintzberg, H., 1994. The rise and fall of strategic planning. Harvard Business Review $72(1), 107-114$. 
Mishra, M., Kim, D., Lee, D.H., 1996. Factors affecting new product success: crosscountry comparisons. Journal of Product Innovation Management 13 (6), 530-550.

Nesheim, J., 1997. High-tech start-up. Nesheim, Saratoga, CA.

Oakey, R., Rothwell, R., Cooper, S., 1988. The management of innovation in hightechnology small firms-Innovation and regional development in Britain and the United States. Pinter, London.

Perlmuter, D., 2003. How to maintain competitiveness in high-tech. Haaretz newspaper 20.10. 2003 (in Hebrew).

Porter, M.E., 1980. Competitive strategy: Techniques for analyzing Industries and competitors. The Free Press, New York, NY.

Reeble, D., 1990. High-technology Industry. Geography 75, 361-364.

Reynolds, P., 1993. High performance entrepreneurship: what makes it different? Frontiers of Entrepreneurship Research. Wellesley, Babson College, MA.

Roberts, E.B., 1968. Entrepreneurship and technology: a basic study of innovators; how to keep and capitalize on their talents. Research Management 11 (4), 249-266.

Roberts, E.B., 1978. What do we know about managing R\&D. Research Management 21, 26-30.

Roberts, E.B., 1979. Stimulating technological innovation-Organizational approaches. Research Management 22, 6-11.

Roure, J.B., Keely, R.H., 1990. Predictors of success in new technology-based ventures. Journal of Business Venturing 5 (4), 201-220.

Roure, J.B., Maidique, M.A., 1986. Linking pre-funding factors and high-technology venture success: an exploratory study. Journal of Business Venturing 1 (3), 295306.

Sapienza, H.J., 1992. When do venture capitalists add value? Journal of Business Venturing 7 (1), 9-27.

Sapienza, H.J., Manigart, S., Vermeir, W., 1996. Venture capitalist governance and value added in four countries. Journal of Business Venturing 11 (6), 439-469.

Slater, S. F., Narver, J.C., 1995. Market orientation and the learning organization. Journal of Marketing 59 (3), 63-74.

Slater, S.F., Narver, J.C., 1998. Customer-led and market-oriented: let's not confuse the two. Strategic Management Journal 19 (10), 1001-1006.

Slater, S.F., Narver, J.C., 1999. Market-oriented is more than being customer-led. Strategic Management Journal 20 (12), 1165-1168. 
Souder, W.E., 1977. An exploratory study of the coordinated mechanism between R\&D and marketing as an influence on the innovation process. Final Report to the National Science Foundation, University of Pittsburgh, School of Engineering, Pittsburgh, PA.

Souder, W.E., 1981. Disharmony between R\&D and marketing. Industrial Marketing Management 10 (1), 67-73.

Specht, P.H., 1993. Munificence and carrying capacity of the environment and organization formation. Entrepreneurship Theory and Practice 17 (2), 77-86.

Steinberg, J., 1999. Taking the long view. Israel high-tech Investor 5, 18-19.

Stuart, R., Abetti, P.A., 1987. Start-up venture: towards the prediction of initial success. Journal of Business Venturing 2 (3), 215-230.

Traston, I., Sarusi, Y., Kochavi, D., Zisapel J., Ayalon, E., 2002. The technology industry as a growth lever. Working paper for the Herzeliya Conference, December 2002.

Von Hippel, E.A., 1978. Users as Innovators. Technology Review 80, 30-39.

Wind, Y., 1981. Marketing and other business functions. Research in Marketing, Vol. V, Jagdish and N. Sheth (Eds.) Greenwich, CT: Jai Press.

Wind, Y., 1982. Product policy: Concepts, methods and strategy. New York: AddisonWesley.

Young, H.C., 1973. Product development setting, information exchange and marketingR\&D coupling. Ph.D. dissertation. Northwestern University, Chicago, Ill.

Zacharakis, A.L., Shepherd, D.A., 2001. The nature of information and overconfidence on venture capitalists' decision making. Journal of Business Venturing 16 (4): 311332.

Schaul Chorev is a doctoral student at Pec's university in Hungary and is currently spending one year as a research fellow at the Centre for Entrepreneurship at Aberdeen Business School, Robert Gordon University. Schaul received his BSc degree in Electrical Engineering from the Technion in Haifa, Israel in 1979 and his MBA degree from the University of Oregon in 1990. $\mathrm{He}$ has a long international working experience in Israel and overseas as an electronic engineer and in marketing of high- tech systems. His current research interests are primarily related to high-tech entrepreneurship with focus on marketing and strategies of high- tech start-ups.

Alistair R Anderson, is Professor of Entrepreneurship and Director of the Centre for Entrepreneurship at Aberdeen Business School, Robert Gordon University in Aberdeen, Scotland. After some 20 years of starting and running small businesses, his curiosity about entrepreneurial people drove him to study entrepreneurship. Unfortunately he found that rather than answering his questions, he simply found more that there were many more interesting questions! He is still trying to answer some of them, especially in the social realms of entrepreneurship. Current themes being explored are social capital, social constructions and associated topic areas. 